\title{
PREVALENCE OF HEPATITIS-B AMONG THE VOLUNTARY BLOOD DONORS AT THE DEPARTMENT OF IMMUNOHAEMATOLOGY AND BLOOD TRANSFUSION IN A TERTIARY CARE HOSPITAL
}

\author{
Radhika Arumugam Rangaraj1, Gayathri Purushothaman²
}

${ }^{1}$ Senior Assistant Professor, Department of Pathology, Government Vellore Medical College, Vellore, Tamilnadu. ${ }^{2}$ Senior Assistant Professor, Department of Pathology, Government Vellore Medical College, Vellore, Tamilnadu.

\section{ABSTRACT}

\section{BACKGROUND}

Hepatitis B virus infection is a global health problem. Approximately, 30\% of world's population have serological evidence of either current or past infection with hepatitis B virus.(1) HBV causes a spectrum of diseases from self-limited hepatitis to acute fulminant and chronic hepatitis, which may result in sequelae like liver cirrhosis and hepatocellular carcinoma.

The aim of this study is to study the seroprevalence of HbsAg among the voluntary blood donors.

\section{MATERIALS AND METHODS}

It is a retrospective descriptive study. $5 \mathrm{~mL}$ blood sample was collected from the blood bag of each donor. $2 \mathrm{~mL}$ blood was kept for testing Hepatitis B. ELISA kit was used for the screening of the donors. All reactive samples were tested again using the same ELISA kit. Samples showing repeat test reactivity on both methods were considered positive and were included for calculation of seroprevalence.

\section{RESULTS}

Total number of donors were 24,291. Out of them, only 349 were seropositive (prevalence of 1.5\%, i.e. low prevalence).

\section{CONCLUSION}

Vellore region is one of the few regions from India where seroprevalence of HBsAg is low.

\section{KEYWORDS}

Hepatitis B, Voluntary Blood Donor, Awareness.

HOW TO CITE THIS ARTICLE: Rangaraj RA, Purushothaman G. Prevalence of hepatitis-B among the voluntary blood donors at the department of immunohaematology and blood transfusion in a tertiary care hospital. J. Evolution Med. Dent. Sci. 2018;7(04):492494, DOI: $10.14260 /$ jemds/2018/109

\section{BACKGROUND}

Hepatitis B virus infection is a global health problem. Approximately, $30 \%$ of world's population have serological evidence of either current or past infection with hepatitis B virus.(1) HBV causes a spectrum of diseases from self-limited hepatitis to acute fulminant and chronic hepatitis, which may result in sequelae like liver cirrhosis and hepatocellular carcinoma. (2)

As per WHO guidelines, countries are classified on the basis of endemicity of hepatitis $\mathrm{B}$ virus infection into high ( $8 \%$ or more), intermediate $(2 \%-7 \%)$ or low (less than $2 \%$ ) incidence countries. The prevalence of chronic HBV infection in India ranges from $2 \%$ to $10 \%$ as shown by different studies. India therefore comes under the intermediate-tohigh endemic category. (3) This infection is mainly transmitted through blood and blood products, vertically from mother to neonates and body secretions.(4)

Blood transfusion associated HBV infection continues to be a major problem in India, even after adoption of mandatory screening of hepatitis B surface antigen (HBSAg) by enzyme-linked immunosorbent assay.(5)

'Financial or Other Competing Interest': None.

Submission 09-06-2017, Peer Review 04-01-2018,

Acceptance 11-01-2018, Published 22-01-2018.

Corresponding Author:

Dr. Radhika Arumugam Rangaraj,

No. 682 A/2, Phase-2,

Sathuvachari.

E-mail: radimadi2006@gmail.com

DOI: $10.14260 /$ jemds $/ 2018 / 109$
The disease is caused by an enveloped, partial doublestranded DNA virus.(6-8) Hepatitis B virus infects the liver. The liver functions are impaired, while the virus replicates in the hepatocytes. $(9,10)$ Hepatitis and liver damage arise as a consequence of the immune response to the virus in the liver cells.(11)

Hepatitis B virus is present in the blood, blood products and body fluids such as vaginal secretions and in low concentrations in the saliva of active carriers. ${ }^{(12)}$ The average incubation period of the virus is 90 days from the time of exposure to onset of symptoms, but many vary from 6 weeks to 6 months.(13,14) This study arises to determine the trends in hepatitis $B$ virus.

It is a well-known fact that transfusion of blood and blood components as a specialised modality of patient management has been saving millions of lives worldwide each year. Amongst the undesirable complications arising out of transfusion of blood and blood products, transmission of certain infections like HIV, HBV and HCV are most significant for the long-term detrimental side effects. Meticulous pretransfusion testing and screening particularly for transfusion transmitted infections (TTI) is the need of the hour.(1) Obviously, the complications arising out of improperly tested or secured blood units before transfusion are included as integral part of such mistakes. It should be obligatory on those who are involved in transfusion of blood to a patient for saving his life that the blood transfusion does not harm the patient.(3) Morbidity and mortality resulting from transfusion of infected blood have far reaching consequences, not only for the recipient themselves but also for their families. Their 
communities and the wider society.(4) Only continuous improvement and implementation of donors selection, sensitive screening tests and effective inactivation procedures can ensure the elimination or at least reduction of the risk of acquired transfusion transmitted infections.(5) This study aims to study the seroprevalence of transfusion transmitted infections among voluntary blood donors and also to do a yearly comparison and study the trend of incidence of HBV positive cases.

\section{MATERIALS AND METHODS}

\section{Study Site}

The study was conducted over a period of five years from 2011 January to 2015 December at Government Vellore Medical College blood bank in the Department of Immunohaematology and Blood Transfusion. Blood donors were voluntary or either replacement donors. Donors were screened by the standard criteria for donor fitness. They were carefully selected for donation by trained personnel after medical examination and target questionnaire.

\section{Study Design}

It is a retrospective descriptive study of serum markers HBV. Our target population consisted of all voluntary blood donors of this blood bank. Serodiagnosis of all the samples were made. The study was performed based on age and sex-wise distribution and prevalence of Hepatitis B virus.

\section{Inclusion Criteria}

Clinically healthy individuals between 18 - 65 years of age with body weight of above $45 \mathrm{kgs}$, haemoglobin above 12.5 gms/dL and no significant medical or surgical history were qualified for the donation process.

\section{Exclusion Criteria}

All professional donors and subjects with a history of liver disease were excluded from the study. Persons belonging to high-risk groups such as patients from thalassaemia clinics, pregnant women, dialysis patients and drug abusers were excluded from the study.

Sera of all qualified blood donors were screened for hepatitis B virus, hepatitis C virus, HIV, syphilis and malaria. Screening for hepatitis B surface antigen in all the serum samples collected were performed.

\section{RESULTS}

Out of 24,291 donors, 22,289 were males and 2002 were females with male-to-female ratio being 8.7: 1

\begin{tabular}{|c|c|c|c|c|c|}
\hline Year & Total Donor & \multicolumn{2}{|c|}{ Male Donors } & \multicolumn{2}{c|}{ Female Donors } \\
\hline & & No. & \% & No. & \% \\
\hline 2011 & 3585 & 3145 & $88 \%$ & 440 & $12 \%$ \\
\hline 2012 & 4689 & 4165 & $89 \%$ & 524 & $11 \%$ \\
\hline 2013 & 4500 & 4177 & $93 \%$ & 323 & $7 \%$ \\
\hline 2014 & 5949 & 5597 & $94 \%$ & 352 & $6 \%$ \\
\hline 2015 & 5568 & 5205 & $93 \%$ & 363 & $7 \%$ \\
\hline
\end{tabular}

Table 1. Gender Distribution among Blood Donors

The overall Hepatitis B surface antigen positive prevalence in the present study was $1.5 \%$. In the present study which was conducted over a period of five years from 2011 to 2015 the total number of donors is on the rise, but the percentage of voluntary donors with hepatitis infection is gradually decreasing which is a good sign of improving awareness among the people. This once again indicates that this region is a low prevalent area.

\begin{tabular}{|c|c|c|c|c|c|c|c|}
\hline Year & $\begin{array}{c}\text { Total } \\
\text { Donors }\end{array}$ & $\begin{array}{c}\text { Male Positive } \\
\text { Donors }\end{array}$ & Percentage & $\begin{array}{c}\text { Female Positive } \\
\text { Donors }\end{array}$ & Percentage & $\begin{array}{c}\text { Total HBsAg } \\
\text { Positive Donors }\end{array}$ & Percentage \\
\hline 2011 & 3585 & 75 & $2.09 \%$ & 12 & $0.33 \%$ & 87 & $2.5 \%$ \\
\hline 2012 & 4689 & 64 & $1.37 \%$ & 11 & $0.23 \%$ & 75 & $1.6 \%$ \\
\hline 2013 & 4500 & 48 & $1.06 \%$ & 4 & $0.08 \%$ & 52 & $1.6 \%$ \\
\hline 2014 & 5949 & 81 & $1.36 \%$ & 5 & $0.08 \%$ & 86 & $1.5 \%$ \\
\hline 2015 & 5568 & 45 & $0.80 \%$ & 4 & $0.07 \%$ & 49 & $0.88 \%$ \\
\hline \multicolumn{7}{|c|}{ Table 2. Positive Gender Distribution among Blood Donors } \\
\hline
\end{tabular}

The table for gender distribution reflects that the number of male donors with hepatitis infection is more when compared to the female donors. The reason might be because on the whole male donors are more when compared to female donors. The decrease in the number of female donors might be due to certain religious taboos and physiological reasons.

The HBsAg marker was higher among the male donors (89.68\%) compared to the female donors (10.31\%).

\begin{tabular}{|c|c|c|c|c|c|c|c|}
\hline Age/Year & $\mathbf{2 0 1 1}$ & $\mathbf{2 0 1 2}$ & $\mathbf{2 0 1 3}$ & $\mathbf{2 0 1 4}$ & $\mathbf{2 0 1 5}$ & Total & \% \\
\hline $20-30$ & 28 & 33 & 40 & 25 & 28 & 154 & $44 \%$ \\
\hline $31-40$ & 26 & 32 & 25 & 23 & 22 & 128 & $37 \%$ \\
\hline $41-50$ & 10 & 20 & 18 & 10 & 1 & 59 & $17 \%$ \\
\hline $51-60$ & 3 & 4 & 0 & 0 & 1 & 8 & $2.2 \%$ \\
\hline Total & $\mathbf{6 7}$ & $\mathbf{8 9}$ & $\mathbf{8 3}$ & $\mathbf{5 8}$ & $\mathbf{5 2}$ & $\mathbf{3 4 9}$ & \\
\hline & Table 3. Age Wise Distribution of Positive Cases \\
among the Voluntary Blood Donors \\
\hline
\end{tabular}

Hepatitis B markers were significantly higher in the age group of 20-30 years and it was lower in the age group of 5160 years. Young voluntary blood donors are more in number when compared to older individuals. Non-communicable diseases like diabetes, obesity and hypertension are more prevalent among the older people, which might be the reason for the setback.

\section{DISCUSSION}

According to India Drugs and Cosmetics Act,(15) each blood unit has to be tested for the hepatitis B viral infection. In our study, a total of 24,291 blood donors were tested and overall seroprevalence of hepatitis B surface antigen was observed to be $1.5 \%$. This seroprevalence rate was correlated with Suresh B Sonth et al.(16) In their study, they showed a prevalence rate of $1.94 \%$ among the voluntary blood donors. This is contrary to the study conducted by Mohd. Yonus Shah et al,(17) which showed a lower prevalence rate of $0.35 \%$. The lower prevalence in their study may be due to $85 \%$ of blood donors 
were literate. According to the WHO classification, this region of Vellore qualifies as a low prevalence area (less than $2 \%$ ). In our study, the seroprevalence rate was higher in the male donors compared to the female donors. This may be due to the number of male voluntary donors outnumbering the number of female donors. A higher seroprevalence rate were also reported by Jain Atul et al.(18) In our study the highest HbSAg seroprevalence rate was observed in the age group of 20 - 30 years, which is comparable with the study conducted by Bagiyalakshmi $\mathrm{V}$ et al.(19)

This finding is contrary to the study conducted by Kamel E et al,(20) which showed a higher rate in the age group of 3039 years. The higher seroprevalence in youths in our study demonstrates the need for further re-intensification of preventive programmes that aim at high-risk behaviour change, as this is the most productive and economically viable group of population. Ensuring the safety of the patient by reducing the residual risk of transmission, transmitted infections are the concern of every transfusion centre. Public awareness programmes, educational and motivational programmes, mass immunisation programmes, ensuring $100 \%$ voluntary blood donation, implementation of strict pre-donation counselling and donor selection criteria will be effective in decreasing the hepatitis B infection rate.

\section{CONCLUSION}

This study has determined the seroprevalence of Hepatitis B infection among the voluntary blood donors of Government Vellore Medical College, Adukkamparai. To reduce the prevalence of transfusion transmitted Hepatitis B, a comprehensive screening of blood donors with recommended methods, strict donor selection criteria, better education of donors and improved prophylactic measures at public level should be implemented to ensure the safe blood donation.

\section{REFERENCES}

[1] WHO certified: hepatitis B: world health fact organisation sheet 204, revised 2008.

[2] Chowdhury A. Epidemiology of hepatitis B virus infection in India. Hep B Annual 2004;1(1):17-24.

[3] WHO certified, prevention of hepatitis B in India, an overview World Health Organization, New Delhi 2002.

[4] Surendra K, Prakash G, Tiwari BR, et al. HBs Agserosurveillance among Nepalese blood donors. Annuals of Tropical Medicine in Public Health 2008;1(1):15-8.

[5] Lavanya V, Viswanathan T, Arul S, et al. Prevalence of hepatitis B virus among blood donors with antibodies to hepatitis B core antigen. International Journal of Medicine and Medical Sciences 2012;4(6):128-37.

[6] Taylor JM, Parcell RH, Farcip. Hepatitis D delta virus. ln: Knipe DM, Howley PM. Fields, virology. $6^{\text {th }}$ edn. Philadelphia, Lippincott Williams Wilkins, 2013.

[7] Tong S, Li J, Wands JR, et al. Hepatitis B virus genetic variants, biological properties and clinical implications. Emerg Microbes Infect 2013;2(3):e10.
[8] Tong MJ, Hsu L, Chang PW, et al. Evaluation of current treatment recommendations for chronic hepatitis B: a 2011 update. J Gastroenterol Hepatol 2011;26(5):82935.

[9] Adams DH, Hubscher SG. Systemic viral infections and collateral damage in the liver. Am J Pathol 2006;168(4):1057-9.

[10] Vinciquerra M, Mazzoccoli G, Piccoli C, et al. Exploitation of host clock gene machinery by hepatitis viruses B and C. World J Gastroenterol 2013;19(47):8902-9.

[11] Rehermann B, Nascimbeni M. Immunology of hepatitis $B$ virus and hepatitis $C$ virus infection. Nat Rev Immunol 2005;5(3):215-29.

[12] Villarejos VM, Visona KA, Gutierrez A, et al. Role of saliva, urine and feces in the transmission of type $B$ hepatitis. N Engl J Med 1974;291(26):1375-8.

[13] Weinbaum CM, Williams I, Mast EE, et al. Recommendations for identification and public health management of persons with chronic hepatitis B virus infection. MMWR Recomm Rep 2008;57(RR-8):1-20.

[14] Mast EE, Margolis HS, Fiore AE, et al. A comprehensive immunisation strategy to eliminate transmission of hepatitis B virus infection in the United States; recommendations of the advisory committee on immunisation practices. (ACIP) Part I, Immunzation of infants, children and adolescents. MMWR Recomm Rep 2005;54(RR-16):1-31.

[15] The Gazette of India: Extraordinary, Ministry of Health and Family Welfare, notification GSR 28(E) 22 Jan 1993.

[16] Sonth SB, Gokale S, Hadapad D, et al. Prevalence of hepatitis $\mathrm{B}$ virus infection among blood donors. International Journal of Current Microbiology and Applied Sciences 2015;4(10):915-8.

[17] Shah MY, Naqash MM, Shah FY. Seroprevalence of hepatitis $\mathrm{b}$ in healthy blood donors at a teaching hospital of Kashmir (skims medical college and hospital Bemina, Srinagar): a restrospective study of five years. Int J Res Med Sci 2016;4(2):509-11.

[18] Atul J, Ruhi M, Seema G, et al. Prevalence of hepatitis B among the voluntary blood donors at the department of immunohaematology and blood transfusion of MGM hospital Kamothe, Navi Mumbai. International Journal on Recent Trends in Life Science and Mathematics 2014;1(4):5-8.

[19] Bagiyalakshmi V, Gopal R, Siva R. Prevalence of hepatitis $\mathrm{B}$ virus infection among voluntary blood donors at a tertiary care hospital blood bankTrichirapalli. International Journal of Scientific Study 2017;4(10):105-8.

[20] El Beltagy KE, Al Balawi IA, Almuneef $\mathrm{M}$, et al. Prevalence of hepatitis B virus markers among blood donors in a tertiary hospital in Tabuk, northwestern Saudi Arabia. Int J Infect Dis 2008;12(5):495-9. 